\title{
A SARS COVID-19 VÍRUS OKOZTA HELYZET A HAZAI KORA GYERMEKKORI INTÉZMÉNYEKBEN
}

Szerző:

Vargáné Nagy Anikó (PhD.)

Debreceni Egyetem

(Magyarország)

Szerző e-mail címe:

vnaniko@ped.unideb.hu
Lektorok:

Pálfi Sándor (PhD.)

Debreceni Egyetem

(Magyarország)

Molnár Balázs (PhD.)

Debreceni Egyetem

(Magyarország)

...és további két anonim lektor

Vargáné Nagy Anikó (2021): A SARS COVID-19 okozta helyzet a hazai kora gyermekkori intézményekben. Különleges Bánásmód, 7. (4). 101-107. DOI 10.18458/KB.2021.4.101

\begin{abstract}
Absztrakt
A tanulmány egyfajta országjelentést tár elénk. A SARS-COVID-19 vírus következtében kialakult járványveszély hatásait elemzi a hazai kora gyermekkor intézményekben, különös tekintettel az óvodákra. Ismerteti a 2020. március elejétől 2020. szeptemberig terjedô időszak helyi és kormányrendeleteit, amelyek az óvodák múködését szabályozták. Ismerteti az óvodapedagógusok és óvodai dolgozók járványveszély ideje alatti rendkívüli tevékenységeit, és azokat a kihívásokat, amelyekkel a kialakult helyzetben kellett szembenézniük.
\end{abstract}

Kulcsszavak: SARS-COVID-19, kora gyermekkori intézmények, helyzetjelentés

Diszcilína: pedagógia

\begin{abstract}
Absztrakt
THE EFFECT OF SARS-COVID-19 VIRUS IN EARLY CHILDHOOD EDUCATION IN HUNGARY

This paper is a report. The paper analyzes the effects of the pandemic of SARS-COVID-19 in early childhood education and care in Hungary, especially in kindergartens. The paper presents the local and government decrees, which control the operation of kindergartens from March 2020 till September 2020. The paper presents the early childhood educators' and assistants1 extraordinary activities during the pandemic and those challenges they had to face.
\end{abstract}

Keywords: SARS-COVID-19, Early Childhood Institutions, Status Report

Discipline:pedagogy 


\section{Bevezetés}

A Covid19-ként említett betegséget az ENSZ egészségügyi világszervezete a WHO 2020. március 11-én nyilvánította világjárvánnyá. A magyar kormány Operatív Törzset hozott létre az új koronavírus elleni küzdelem érdekében, amelynek a koronavirus.gov.hu címú honlapján jelennek meg információk a hatósági intézkedésekről. A magyar kormány (40/2020. (III. 11. Kormányrendelet) rendelete az élet- és vagyonbiztonságot veszélyeztető tömeges megbetegedést okozó humánjárvány következményeinek elhárítása, a magyar állampolgárok egészségének és életének megóvása érdekében Magyarország egész területére veszélyhelyzetet hirdetett ki. A 45/2020. (III.14.) Korm. rendelet 2.\$-a értelmében a bölcsődei ellátást végző intézmény, valamint az óvoda elhelyezkedése szerinti települési önkormányzat polgármestere 2020. március 16. napjától a bölcsődei és az óvodai ellátást végző intézmények esetében rendkívüli szünetet rendelhet el. A polgármester a szünet elrendeléséről soron kívül tájékoztatja az emberi erőforrások miniszterét.

A kormányrendelet értelmében a hazai óvodák nem fogadhattak gyermekeket, bizonytalan ideig fel kellett függeszteniük nevelő tevékenységüket.

\section{Óvodapedagógusok általi tevékenységek}

A rendelet korábban nem tapasztalt, váratlan helyzet elé állította a kora gyermekkori intézményeket és az érintett szereplőket. Az új helyzetben központi, egységes intézkedések nem segítették az érintett intézményeket, a kormányrendelet értelmében a fenntartók az intézményekben nevelés nélküli munkát, majd dolgozóinak otthoni munkavégzést rendeltek el.

A családokat különösen súlytotta a kialakult helyzet, hiszen a szülők egyrésze otthonról, home office-ban folytatta a munkáját, míg mások elveszítették a munkájukat. Mindemellett meg kellett oldaniuk a kisebb gyermekek kiesett intézményes ellátását, és az iskolás korúak digitális oktatásának a segítését. Az, hogy a gyerek tud hol lenni napköz- ben, miközben a szülő dolgozik, a szülők számára társadalmi hovatartozástól függetlenül létfontosságú kérdés, és alap funkciója az intézménynek. A vírus okozta krízishelyzetben az óvodával nagy arányban szakadt meg a kapcsolata a szülóknek. Magyarországon a hátrányos helyzetú gyermekek létszáma magas a köznevelési intézményekben, a családjukkal való kapcsolattartás eleve nehezebb és kutatások bizonyítják, hogy a hátrányos helyzetû szülők a pedagógussal való személyes, bizalmi kapcsolatot preferálják. Voltak olyan hátrányos helyzetû́ körzetek, ahol az óvodavezető személyesen kereste fel a családokat és értesítette őket a kialakult veszélyhelyzetről és az intézmény bezárásáról, hiszen ők nem rendelkeznek esetenként telefonnal sem.

Az állami fenntartású, önkormányzati óvodákban az óvodapedagógusoknak a helyi rendelkezések alapján a munkáltató a közoktatási intézmények (iskolák) mintájára az óvodákban is a digitális munkavégzést irányozott elő annak érdekében, hogy az alkalmazottak munkavégzése igazolva legyen, és így a fizetésüket megkaphassák. A foglalkoztatás megváltozott szabályait 47/2020. (III. 18.) kormányrendelet rögzítette. A pedagógusok vagy rendszeresen bejártak az intézménybe vagy otthonról tartották a kapcsolatot a szülőkkel. Az intézmény múködését szabályozó dokumentumában rögzített munkafeladatokat kellette ellátniuk és az otthoni munkavégzést heti jelentéssel kellett igazolniuk a fenntartó felé.

A rendelet nehezen érintette a családokat, hiszen egyik napról a másikra kellett gyermekük elhelyezésérôl gondoskodniuk annak tudatában, hogy az idősebb generáció esetleges megbetegedését könynyen előidézheti a gyermekek felügyeletének családon belüli átszervezése, és egyben át is alakította az életüket. A múködéssel kapcsolatos átállást követően átgondolást igényelt a gyermekek otthoni személyiségfejlődés támogatásának igénye. (BaloghSzerepi, 2020)

A távmunka teljesen ismeretlen fogalom volt az óvodapedagógusok számára. Munkájukhoz a 
gyermekek szeretetteljes fogadása, a testi érintés, az ölelés, és a szülőkkel való napi szóbeli kapcsolattartás tartozik.

Ezt váltotta fel egy informatikai eszköz, amely egészen más kapcsolattartási formát és kompetenciákat igényelt. Általánosságban elmondható, hogy IKT-eszközökkel (információs-és kommunikációs technológia) az óvodák sem megfelelően vannak ellátva. Az óvodapedagógusok megújulásra képessége előtérbe helyezte az innovatív törekvéseket és az IKT eszközök alkalmazását, igaz, a személyes kontaktust nem képes pótolni sem egy videóanyag, hangfájl, vagy ppt bemutató. Az ölelés, a kedves szavak, a mimika és gesztusok, a beszédet még kevésbé értő gyermekek számára a nonverbális gesztusok, a csoportkohézió ilyen eszközökkel nem helyettesíthető.

Általános gyakorlattá vált az óvodák esetében a zárt Facebook csoportok létrehozása a szülők elérése érdekében. A szülők számára a gyermekek és az óvodai csoport fejlettségének ismeretében elsősorban offline, a gyermekekkel együtt végezhető, mozgásos otthoni játékos tevékenység ajánlási formákat, élményszerzési lehetőségeket, ajánlottak. A módszertani ajánlásoknál figyelembe vették a gyermekek személyiségét, érdeklődését, egyéni képességeit. Így kívántak online formában segítséget nyújtani minden szülő részére a rendelkezésükre álló infokommunikációs eszközök használatával. Segítő szándékuk szerint pedagógiai tudásukkal, ötleteikkel támogatták a szülőket, hogy hasznosan töltsék el a családok az otthon megnövekedett közös időt. Ez az időszak lehetőséget teremtett a pedagógusoknak arra, hogy az egyéni pedagógusi kompetenciáikat erôsítsék, szakmailag megújulhassanak. Videóra vett meséket mondtak a gyerekeknek, báboztak, dalokat énekeltek, verseket mondtak, továbbá otthon is elvégezhető kreatív, kézműves tevékenység ötleteket, játékokat küldtek a szülők számára. A családdal együtt közösen játszható játékötleteket gyűjtöttek és továbbítottak a szülőknek. A pedagógusok igyekeztek mentálhigiénés, szituációs játékot becsempészni a csoport életébe ezzel is segítve az élmények feldolgozását, elfogadását.

Az online távnevelés alkalmazásában az óvodák igyekeztek a szülői nevelést támogató elvet vallani, ami az óvoda gyermekképének is alapköve, így személyes tanácsokra, együtt végzett tevékenységekre, élményekre és emlékekre utaló eseményekre felfüzött tevékenység ajánlásokkal támogatták a szülők gyermeknevelését. (Balogh-Szerepi, 2020) Szülői visszajelzések alapján ugyanakkor tapasztalható volt az is, hogy az óvodapedagógusok olyan jellegű feladatokat kértek a szülőktől, amelyeknek a megvalósításához az otthoni feltételek, eszközök nem adottak, valamint túlmutatott egy óvodáskorú gyermek képességein.

A szülők többféleképpen reagáltak az óvodapedagógusok által kínált tevékenység ötletekre. Voltak, akik első perctől kezdve folyamatosan aktívak voltak, elvégezték a kért feladatokat, visszajelzésekkel éltek a pedagógusok számára. Voltak olyan családok, akik informatikai eszközök, vagy érdeklődés, időhiány, a nagyobb, iskolás testvér digitális oktatásának segítése miatt nem éltek az óvoda által kínált javaslatokkal. Az eltérő fejlődésű gyermekek gyógypedagógiai fejlesztése is az online térbe szorult, aminek a hatékonysága nem mérhető fel a személyes kontakt tevékenységgel.

A szülők digitális elérése nem minden esetben működött. Az informatikai tudás és a digitális eszközökhöz való hozzáférés egyenetlen. A hátrányos helyzetű régiókban irreleváns online segítségnyújtásról beszélni, ahol a családok nem rendelkeznek azokkal az eszközökkel, amelyeket az online oktatás feltételez. A hátrányos helyzetű szülők nagy részénél kártyás villanyóra van, s hónap vége felé már nincs pénz feltöltésre, s néhány napig áram sincs. Digitális eszköz, internet kapcsolat pedig egyáltalán nincs. Az iskolások is papíralapon kapták a leckét, aminek megoldásában a szülő általában nem tudott segíteni. A szülőkkel való kapcsolattartás nem csak a korábban alkalmazott, munkaidőn belüli kapcsolattartásra terjedt ki. A szülők a késő esti órákban, és sok esetben hétvégén is igényt tartottak az 
óvodapedagógus segítségére, visszajelzésére.

$\mathrm{Az}$ óvodapedagógusok online is segítették egymást a szakmai megújulás és a módszertani tapasztalatok cseréje érdekében az óvodapedagógiai szakmai közösségi oldalak hasznosításával. A fenntartó hozzájárulásával tisztasági csomagokat juttattak el a rászoruló családokhoz a járvány elleni küzdelemben kiemelten fontos higiéniai szabályok betartására. Az intézményben dekorációkat készítettek, selejteztek, szertárt takarítottak, adminisztrációs feladatokat végeztek. Ezeken túl textíliákat javítottak, babzsákokat varrtak, besegítettek a maszkok készitésébe is az önkormányzat dolgozóinak, illetve az egészségügyben dolgozók részére. Voltak olyan intézmények, ahol a fenntartó rendelkezése alapján az épület felújítása körüli teendőket is a pedagógusok végezték el, pl. kerítés festése, csoportszobák felújitása, festése. A kialakult járványhelyzet miatt a házi segítségnyújtást még több család igényelte. Volt példa arra, hogy az óvodák dolgozói besegítettek a szociális intézmény dolgozóinak, pl. posta, gyógyszertár vagy napi bevásárlások intézésének ellátásában. A dajkák az intézményeket takarították, fertőtlenítettek.

A konyhával is rendelkező intézményekben a konyhai dolgozók heti rendszerességgel hidegélelmet csomagoltak a gyerekeknek. A gyámügyi igazgatásról szóló 1997.évi XXXI. törvény 2121/B.§-a szerint intézményi gyermekétkeztetést szükséges biztosítani a gyermekek részére. A rendszeres gyermekvédelmi támogatásban részesülő gyermekek térítésmentesen kapták az élelmet, de lehetett igényelni másoknak is fizetés ellenében. Az élelem házhoz szállitását az óvodás és iskoláskorú gyermekek részére az óvodai dolgozók koordinálták, ekkor volt alkalmuk a szülókkel is beszélgetni, hiszen a szegregátumokban a lezárás idején sem védőnő, sem családgondozó szakember nem kereste fel a családokat, a családok legközelebbi kapcsolata az óvodával volt.

A 152/2020. (IV. 27.) Kormányrendelet értelmében a fenntartók a településeken ügyeleti rendet ellátó óvodákat jelöltek ki, a rendkívüli szünet idejére a polgármester köteles volt megszervezni a bölcsődés és óvodás korú gyermekek napközbeni felügyeletét. Az ügyeletet azon, fertőző betegségben nem szenvedő gyermekek számára kellett biztosítani, akiknek szülője vagy más törvényes képviselôje - munkavégzés miatt - ezt igényli. A rendelet szerint az ügyelet iránti igény benyújtása nem volt köthető semmilyen alaki feltételhez, ezért akár e-mailben vagy telefonos értesítés útján is benyújthatták. A szülőnek írásban kellett nyilatkoznia arról, hogy a gyermek nem szenved fertőző betegségben. Az önkormányzat az ügyeletet kiscsoportos formában kellett megszervezze, és csoportonként legfeljebb öt gyermek felügyelete volt biztositható.

„2020. május 20-án. a Magyar közlönyben új kormányrendelet jelent meg. A Kormány 215/2020. (V. 20.) Korm. rendelete az óvodák és bölcsődék újranyitásáról."

Az újranyitás elôtt az intézmények felmérték a családoknál az óvodai ellátás igényét, valamint nyilatkoztatták őket a gyermekek egészségi állapotáról. A családok többsége igényelte az óvodai ellátást.

A 2020/2021-es tanév újabb változásokat hozott a kisgyermekeket nevelő intézmények életében. A védelmi intézkedésekről szóló 431/2020.(IX.18.) Korm. rendelet értelmében a köznevelési intézmény területére az ott dolgozókon és a gyermekeken kívül más személy nem léphetett be. Az intézménybe szeptembertől nem mehettek be a szülők, a dajkák, pedagógiai asszisztensek kísérték be a gyerekeket a bejárattól egészen a csoportszobákig. $\mathrm{Az}$ intézménybe belépő gyermekek és felnőttek testhőmérsékletét megmérték, rögzítették, belépési naplót vezettek be, illetve a felnőttek a zárt terekben maszkot viselnek. Az óvodák ezzel a védekezéssel is próbálták a gyermekek és a dolgozók egészségét megőrizni. A mindennapokban nehézséget okoz egy-egy szabály betartása, így pl. a maszk használata, hiszen a beszédértést nehezíti. $\mathrm{Az}$ óvoda több helyiségeinél kézfertőtlenítőt helyeztek ki, amelyek használatát a gyermekeknek is megtanították. Figyelnek a gyakori helyes kézmosásra, valamint az intézmény tisztaságára, 
fertôtlenítésére. A dajkák takarítási naplót vezetnek. A szülők az intézménybe csak indokolt esetben léphetnek be, tiszteletben tartva a szabályokat. A szülői értekezletek elmaradtak, a napi kapcsolattartás a szülőkkel lecsökkent, és az online felületre korlátozódott a korábban létrehozott Messenger csoport vagy telefon segítségével.

A járványügyi készültségi időszak védelmi intézkedéseirôl szóló 431/2020.(IX.18.) Korm. rendelet értelmében 2020. október 1-étől kötelezővé vált a foglalkoztatottak és a gyermekek testhőmérsékletének mérése érkezéskor. Koronavírus fertőzés vagy koronavirus érintettség esetén az adott intézményben csak az Oktatási Hivatal rendelhetett el rendkívüli szünetet.

A Kormány 509/2020. (XI. 19.) Korm. rendelete értelmében többek között a nevelési, intézményekben nevelési, tevékenységet végző dolgozók, SARSCoV-2 koronavírus kimutatására alkalmas rendszeres vizsgálatot és szűrést rendelt el. A fôvárosi és megyei kormányhivatalok szervezésében a koronavírus kimutatására alkalmas antigén gyorsteszttel az Operatív Törzs által meghatározott rendben. A vizsgálaton történő részvétel önkéntes.

$\mathrm{Az}$ intézmények járványügyi intézkedési tervet készítettek, ami a járványügyi helyzetnek megfelelően folyamatosan változó protokoll), amely tartalmazza a dolgozókra és a szülőkre vonatkozó járványügyi szabályokat. Ezek szerint az óvoda épületébe nem lépnek be a szülők, minden szüló nyilatkozatot töltött ki - csak egészséges gyerek jöhet óvodába, a családban előforduló COVID-19 megbetegedést jelezni kell, ajtóban lázmérés és kézfertőtlenítés történik, maszk használata az intézmény területén a szabadtéren is a jelenlegi kormányrendelet szerint kötelező. A szülők jelenleg is élnek azzal a jogukkal, hogy a vírusra való tekintettel nem kötelező az óvodáztatás a gyermek számára.

További nehézséget okozott az óvodapedagógusok és az óvodai dolgozók (dajkák, pedagógiai asszisztensek) lebetegedése. Nagy szervezést és helytállást igényel az óvoda folyamatos múködtetése ezekben az esetekben.

\section{Összegzés}

A COVID 19 vírus okozta helyzet átalakította a család-intézmény kapcsolatát és viszonyrendszerét. A vírus okozta krízishelyzetben az óvodával megszakadt a szülők napi közvetlen kapcsolata. A családok számára az intézményes nevelés alapvető elérhetôsége vált bizonytalanná. Ez a megingott viszony pedig egyaránt érintette a középosztálybeli családokat, ahol a szülők, a korábban kevésbé ismert és elterjedt kifejezés szerint, home office-ban dolgoztak és a hátrányos helyzetû családokat is, akik számára az intézményes nevelés kiegészítő, hátránycsökkentő szerepet is betölt a gyerekek számára. A szülők informatikai tudása, eszközökkel való ellátottsága, és a nevelési-oktatási intézmények iránti attitúdjük sem egyenletes. Általánosságban elmondható, hogy a hagyományosan jól múködő család-óvoda partneri kapcsolatnak nem használ az, hogy a szülők nem mehetnek be az intézménybe, mint, ahogyan a gyermek közösségi életére sincs jól hatással az, ha a szülố nem viszi óvodába. A szülőkkel való hatékony kommunikáció esetében felértékelődnek a személyes találkozások pillanatai. A vírus okozta helyzet nagyban hozzájárult a szülők és gyermekek körében is az óvodai nevelés területei közül az egészséges életmódra nevelés fontosságának tudatosításában. Önfegyelmet követel a védelmi intézkedések betartása.

A kisgyermekes szülők számára komoly leterheltséget jelentett az időszak. A vírus következményei (szülők munkahelyének elvesztése, otthoni munkavégzés nehézségei, a gyermek elhelyezése és ellátásának nehézségei, a kisiskolás gyermek digitális oktatásának nehézségei, kilátástalan élethelyzet, létbizonytalanság, stressz, nagyszülőkkel, rokonokkal, barátokkal való kapcsolattartás nehézsége) megnehezítették a családok életét.

A gyerekek esetében további hátrányt jelentettek az otthoni lakáskörülmények, a játékeszközök, rajzeszközök, a szülői kompetencia hiánya. Az eltérô fejlődésmenetű és a megkésett fejlődésű gyermekek 
fejlesztése (különböző mozgásfejlesztések, gyógypedagógiai fejlesztések, stb.) is az online térbe szorult, amelynek a hátrányai és következményei még fel sem mérhetőek.

A minőségi kora gyermekkori nevelés egyfajta társadalmi befektetési stratégia, amelyet az emberitőke elmélet támaszt alá ahol a kora gyermekkori nevelés a gyermek tanulásának megalapozása, a jövőbe való befektetés. A korai években történő alapozás az élethosszig tartó tanulás része.

Heckmann elmélete szerint a humán tőkébe történő megtérülés mértéke annál nagyobb, minél korábbi életkorban történik a befektetés. (Heckman, 2008) Életciklus befektetés (Lifecycle Benefit) elméletéből tudjuk, hogy minél korábbi életkorban történnek a befektetések, annál magasabbak a beruházások hosszú távú megtérülési rátái. (Heckman, 2008) A kora gyermekkori minőségi gondoskodás széles területen eredményez jobb eredményeket. A minőségi korai tanulási eredmények, mindkét nem esetében magas megtérülési rátájúak. A megtérülés az oktatás, egészség, társadalmi viselkedés, munkahelyi elhelyezkedés területén voltak kimutathatóak, Heckman és munkatársai szerint különös tekintettel a hátrányos helyzetű gyermekekre.

A pedagógusok mentálisan és pszichésen is túlterheltek, mindenki másként élte meg a pandémiát, a bizonytalanságot, a kilátástalanságot és a betegségtől való félelmet. Az óvodapedagógusok elmondása szerint az informatikai tudásuk jelentősen növekedett a járvány kezdete óta. Ez leginkább autonóm tanulás révén a saját szakmai megújulásuk, az adott helyzethez alkalmazkodó módszertani tudásuk tudatos frissítésével járt.

A pedagógusok esetében a hosszú távú hatások között említhetjük a dokumentáció digitalizáció irányába való elmozdulást, a továbbképzések, konferenciák költségkímélő módon szintén az online térbe húzódhatnak.

A COVID-19 vírus okozta helyzet következményeit, hosszú távú hatásait a családok és a koragyermekkori intézmények helyzetére még ezután fogjuk kutatni. A járványhelyzet hatása az intézményen kívüli nevelésre új pedagógus kompetenciákat igényel. Átalakul a szülők-óvodapedagógusok közötti kommunikáció, felértékelődnek a hatékony, online is nyújtható segítségformák.

A gyermekek társas kapcsolataira, beszéd-és mozgás képességének fejlődésére valamint a mentális egészségére vonatkozó következmények egyenlőre megjósolhatatlanok.

\section{Irodalom}

Balogh Beáta,. Szerepi Sándor (2020). A család és az óvoda nevelési funkcióinak összhangja a COVID-19 vírus okozta rendkivüli helyzet tükrében. In Vargáné Nagy Anikó (szerk.): Családi nevelés. Nevelési problémák a családban (717.). Debrecen: Didakt Kiadó.

Egészségügyi Világszervezet (World Health Organization) (2020, March 11) Koronavírus (COVID-19) világjárvány. web: https://www.who.int/

James, Heckman (2008): The Case for Investing in Disadvantaged Young Children. CESifo DICE Report 6(2):3-8

509/2020. (XI. 19.) Kormányrendelet Az egészségügyi és az egészségügyben dolgozók, a nevelési, oktatási intézményekben nevelési, oktatási tevékenységet végző dolgozók, a szociális intézményekben dolgozók, valamint a bölcsődei ellátásban dolgozók SARS-CoV-2 koronavírus kimutatására alkalmas rendszeres vizsgálatáról és az egészségügyi ellátással összefüggő egyes kérdésekről

47/2020. (III. 18.) Kormányrendelet a koronavírus világjárvány nemzetgazdaságot érintő hatásának enyhítése érdekében szükséges azonnali intézkedésekrôl

40/2020. (III. 11. )Kormányrendelet veszélyhelyzet kihirdetéséről.

A 45/2020. (III.14.) Korm. rendelet 2.§-a az élet- és vagyonbiztonságot veszélyeztető tömeges megbetegedést okozó humánjárvány megelōzése, 
illetve következményeinek elhárítása, a magyar állampolgárok egészségének és életének megóvása érdekében elrendelt veszélyhelyzet során teendô intézkedésekről

A gyermekek védelméról és gyámügyi igazgatásról szóló 1997.évi XXXI. törvény 21-21/B.§
A 152/2020. (IV. 27.) Kormányrendelet a veszélyhelyzet során a gyermekek napközbeni felügyeletével kapcsolatos intézkedésekről

215/2020. (V. 20.) Korm. rendelete az óvodák és bölcsődék újranyitásáról.

A védelmi intézkedésekről szóló 431/2020.(IX.18.) Kormányrendelet a járványügyi készültségi időszak védelmi intézkedéseiről 